\title{
Preschool Child Care and Child Well-Being in Germany Does the Migrant Experience Differ?
}

Kaiser, Micha; Bauer, Jan Michael

Document Version

Accepted author manuscript

Published in:

Social Indicators Research

DOI:

10.1007/s11205-019-02064-5

Publication date:

2019

License

Unspecified

Citation for published version (APA):

Kaiser, M., \& Bauer, J. M. (2019). Preschool Child Care and Child Well-Being in Germany: Does the Migrant

Experience Differ? Social Indicators Research, 144(3), 1367-1390. https://doi.org/10.1007/s11205-019-02064-5

Link to publication in CBS Research Portal

\section{General rights}

Copyright and moral rights for the publications made accessible in the public portal are retained by the authors and/or other copyright owners and it is a condition of accessing publications that users recognise and abide by the legal requirements associated with these rights.

Take down policy

If you believe that this document breaches copyright please contact us (research.lib@cbs.dk) providing details, and we will remove access to the work immediately and investigate your claim. 


\section{Preschool Child Care and Child Well-Being in Germany: Does the Migrant Experience Differ?} Micha Kaiser and Jan Michael Bauer

Journal article (Accepted version*)

\section{Please cite this article as:}

Kaiser, M., \& Bauer, J. M. (2019). Preschool Child Care and Child Well-Being in Germany: Does the Migrant Experience Differ? Social Indicators Research, 144(3), 1367-1390. https://doi.org/10.1007/s11205-01902064-5

This is a post-peer-review, pre-copyedit version of an article published in Social Indicators Research. The final authenticated version is available online at:

00l: https://doi.org/10.1007/s11205-019-02064-5

* This version of the article has been accepted for publication and undergone full peer review but has not been through the copyediting, typesetting, pagination and proofreading process, which may lead to differences between this version and the publisher's final version AKA Version of Record. 


\section{This is a pre-proof version of the article published as:}

Kaiser, M., Bauer, J.M. Preschool Child Care and Child Well-Being in Germany: Does the Migrant Experience Differ?. Soc Indic Res 144, 1367-1390 (2019). https://doi.org/10.1007/s11205-019-02064-5

Preschool child care and child well-being in Germany: Does the migrant experience differ?

\section{MICHA KAISER $^{1} \&$ JAN M. BAUER ${ }^{2 *}$}

${ }^{1}$ Institute for Health Care \& Public Management, University of Hohenheim Center for Consumer, Markets and Politics, Zeppelin University

${ }^{2}$ Department of Management, Society and Communication, Copenhagen Business School Abstract

Because the value of preschool child care is under intensive debate among both policy-makers and society in general, this paper analyzes the relation between preschool care and the wellbeing of children and adolescents in Germany. It specifically examines differences in outcomes based on child socioeconomic background by focusing on the heterogeneous effects for migrant children. Our findings, based on data from the German Health Interview and Examination Survey of Children and Adolescents (KiGGS), suggest that children who have experienced child care have a slightly lower well-being overall. For migrant children, however, the outcomes indicate a positive relation. These results remain robust after controlling for selection into child care on observables and using an instrumental variable approach to address potential endogeneity.

JEL Classification: J13, J15, I28

Keywords: Child care, migrants, preschool, well-being, education inequality

\footnotetext{
* The authors would like to thank Vadim Kufenko, Klaus Prettner, and Alfonso Sousa-Poza for their valuable comments and discussion.
} 


\section{INTRODUCTION}

In Germany, the use of preschool child care ranks high on the political agenda and is the subject of an ongoing public debate about its implications for child and family outcomes. Whereas advocates highlight the importance of sufficient public child care to promote female employment and provide equal educational opportunity across social strata, opponents consider the familial environment most beneficial for child development. Because certain political groups are currently promoting legislation to make participation in preschool child care mandatory rather than voluntary, a better understanding of its outcomes is essential.

Although the share of parents who use child care has risen during past decades, discussion of the short and long term effects of its use in the early years is ongoing in both academic and general discourse. Evaluating these effects is important because parents need to know the risks and benefits of early care in order to provide their children with the best opportunities possible, whereas policy-makers need to evaluate its economic and social costs in order to make subsidization decisions that benefit society.

The child care discussion is also related to the recent debate on migrant integration into Germany as increased migration and ethnic segregation raise questions about how to foster migrant children's chances for economic and personal success. Because these children tend to come from families with low socioeconomic status and limited German language skills, they are often disadvantaged. Hence, participation in preschool child care is often promoted as a tool to improve integration into and acculturation to both the public school environment and German society as a whole (Crosnoe 2007; Dhuey 2011; Spiess, Büchel, \& Wagner 2003). In this paper, therefore, we investigate the relation between experiencing preschool child care in Germany and well-being among children and adolescents, especially those from migrant families. The overall aim is to determine whether and to what extent children benefit from the early child care experience. Even though several recent studies have shown preschool child care to be particularly 
beneficial for children from a low socio-economic background (Cornelissen et al, 2017; Felfe \& Lalive, 2018; Felfe, Nollenberger, \& Rodríguez-Planas, 2015), the pathway through which child care does promote graduation rates and adult outcomes are yet unclear (Havnes \& Mogstad, 2015). In this paper we study to which extent individual well-being during school years might be a potential mediating factor contributing to the overall positive effects of preschool child care and how this experience differs between native and migrant children.

We begin the discussion by reviewing the pertinent literature in section 2 , outlining the institutional background in section 3, and describing our methodology and data in section 4 . We report the results of our estimations in section 5 and show their robustness in section 6 . The paper concludes with a discussion of policy implications in section 7 .

\section{RELATED LiteratuRE}

Although evaluations of preschool care are numerous, most are U.S. studies on the relation with language and math skills and/or child behavior (i.e., problem externalization) whose findings are ambiguous. For instance, Burger (2010) drew a generally positive conclusion about the link between early child care and cognitive development, pointing to an overall beneficial impact on children's start in life, with short term effects usually exceeding those in the long term. Likewise, dependent on the quality of the preschool program, several studies provided evidence for a positive relation between experiencing early care and later cognitive development (Belsky 2006; Cryan, Sheehan, Wiechel, \& Bandy-Hedden 1992; Votruba-Drzal, Li-Grining, \& MaldonadoCarreo 2008).

Other evidence, however, suggested that children who experience care often have more problems with social compliance (Belsky 2006; NICHD 2002; NICHD 2004;), although these findings are highly sensitive to care duration and type, as well as to socioeconomic factors like family income and/or social background (NICHD 2001). Belsky (2006), in fact, identified both 
risky and beneficial effects of early center-based care for U.S. children, with center quality positively related to child linguistic and cognitive skills, but the overall duration of care associated with a higher probability of social noncompliance and riskier behavior (Magnuson, Ruhm, \& Waldfogel 2007; NICHD 2003). The age at which the child begins preschool care also seems to be important for various outcomes: Loeb, Bridges, Bassok, Fuller, \& Rumberger (2007) associated a starting age between two and three years with the best academic outcomes but link a longer duration and higher intensity of care with a higher risk of social noncompliance. This negative effect was also identified by Magnuson et al. (2007), who showed that detrimental outcomes tend to persist longer and be more imperishable than any positive effect on math and language skills.

An analysis of U.S. academic data also provided strong evidence for the positive impact of full-day kindergarten on behavioral and schooling outcomes (Cryan et al. 1992), a finding in line with later verification of a positive but diminishing effect on reading and math skills up to the age of 12 (Votruba-Drzal et al. 2008). Moreover, although studies of early preschool child care's long term effects are few, they did provide some evidence of a positive association between early child care and, for instance, labor market participation (Havnes \& Mogstad, 2011) or cognitive achievements in upper social strata (Peisner-Feinberg et al., 2001).

One important factor for the long term development of a child's cognitive ability as well as his language skills is the quality of the early child care environment, including the child-teacher relationship and preschool class size (Peisner-Feinberg et al., 2001). Nonetheless, although several studies emphasized the importance of program quality for later school performance ( Belsky 2006; Care \& Development 2002; Vandell, Belsky, Burchinal, Steinberg, \& Vandergrift 2010), other studies found no support for this link (e.g., Driessen 2004; NICHD 2001). Blau (1999), for instance, using National Longitudinal Survey of Youth (NLSY) data to estimate the effects on child development of several child care quality measures (e.g., group size, staff-child 
ratio), concluded that despite some evidence for a relation between development and child subgroup, on average there is little or no evidence for a causal impact of child care quality. The persistence of early child care effects becomes even more ambiguous when the analysis considers demographic characteristics: once controls are included for a rich set of covariates (e.g., social class, environmental circumstances, occupational status, or migrant background), participation in preschool child care programs is not significantly associated with higher cognitive and noncognitive competency outcomes (NICHD 2001).

Cornelissen et al. (2017) analyzed the impact of preschool (kindergarten) on school readiness and health. They exploited a political reform that subsidizes kindergarten as an exogenous variation to estimate the heterogeneous effects of different subpopulations. They found kindergarten to work as an equalizer for children with differences in observed and unobserved characteristics. That is, their findings suggested that disadvantaged children are less likely to attain kindergarten, even though they tend to benefit the most. On the contrary, children who are most likely to attend kindergarten gain little from preschool child care in terms of overall school readiness. Those findings contrast the idea that observed differences in school readiness are mainly driven by selection into child care.

Using similar methodology, but data from a different German federal state, Felfe \& Lalive (2018) analyzed the effect of child care before the age of three on school readiness and related outcomes. In line with Cornelissen et al. (2017), they found that gains from child care are strongest among low SES children and support the notion that the effect of child care is heterogeneous - a finding echoed by a study of the Spanish child care expansion in the 1990's, where effects mainly driven by children from low educated parents (Felfe, Nollenberger, \& Rodríguez-Planas, 2015). That considering effect heterogeneity is essential, was also emphasized by Havnes \& Mogstad (2015). Exploiting public child care expansion in the 1970's for children aged three to six in Norway, their study revealed positive effects in the lower, but negative effects 
in the higher income distribution. The authors attribute this benefits for the lower-class children to an increase in the likelihood of completing high school and attaining college. Higher levels of education seems however not explained by better cognitive performance and might therefore be mediated by non-cognitive skills.

Focusing on non-cognitive outcomes, Datta Gupta \& Simonsen (2010) found no effects in terms of behavioral measures (measured with the Strengths and Difficulties Questionnaire (SDQ) index) from attending preschool in Denmark. However, they found family day care, as an alternative, to negatively affect boys from low SES households. Additionally, children may benefit through positive effects channeled through their parents as, for instance, the German expansion of early childcare lead to some increases in parental well-being (Schober \& Schmitt, 2017).

The literature evaluating the impact of preschool child care on migrants, particularly, by focusing virtually exclusively on school performance, supports the idea that preschool child care is beneficial for migrant children (Crosnoe, 2007; Dhuey, 2011). For instance, Magnuson et al. (2006) found that the English proficiency of U.S. migrants improves through child care, thereby increasing their school readiness. Likewise, Schlack, Hölling, \& Kurth (2007), relying on the German Health Interview and Examination Survey of Children and Adolescents (KiGGS) data, showed that the preschool daycare participation rate of migrant children in Germany is significantly lower than that of nonmigrant children. They also demonstrated that the share of migrants whose children ever experience preschool child care is significantly lower between the ages of two and three and higher between the ages of five and six but that the risk of mental problems (measured with the SDQ index) is twice as high for migrant children as for nonmigrant children. They identified no negative risk of attending preschool child care on mental problems for their full child sample. Positive effects related to the preschool child care experience of migrant children are also identified by Spiess et al. (2003), who showed that migrant children in 
Germany who experience such care are less likely to be enrolled in lower track secondary education. The authors were unable, however, to detect any positive and significant effect for native children in the same study. Felfe \& Huber (2017) specifically study the benefits of child care for minorities (i.e. Roma) in 12 European countries. At least in the short-term, child care experience was associated with higher levels of literacy and prevalence of vaccination but did not affect language proficiency and social-emotional development.

Given the above findings, the frequent statistical indication of lower child care participation among migrant children is surprising. One potential explanation is that, as shown by Obeng (2007) for migrants from Africa, it may be linked to a parental desire to instill the native cultural identity. In fact, Turney and Kao (2009), in an analysis of pre-kindergarten child care effects on child behavior, documented clear effect differences based on country and ethnicity of origin. They identified no effect, however, on children's feelings of sadness and loneliness, indicators of emotional well-being, a subject that has, to the best of our knowledge, yet to be analyzed in depth in the context of preschool child care outcomes.

Overall, however, empirical evidence on the relationship between early child care and overall well-being of children and adolescents is limited, which motivates our present attempt to glean new insights into the relation between preschool child care and psychometric measures for schoolchildren. As suggested by Havnes \& Mogstad (2015), the positive effects of child care seems mainly mediated by non-cognitive skills and overall well-being during school years might be an important factor contributing to higher graduation rates. In particular, we analyze the heterogeneous relationship for native German and migrant children, which is important when preschool child care is considered as a public instrument for the integration of migrant children.

\section{Institutional BaCkground ANd Preschool Child CaRe in Germany}


Preschool child care in Germany is organized into two phases based on child age. Between six months and three years, children can go to nursery school (Kindertagesstätte, henceforth Kita), after which they usually transfer to kindergarten before going to elementary school at around age six. Whereas regular schooling is compulsory, preschool child care is voluntary and allows families to choose a range of options from infrequent morning care to full day care during the work week. Although some families rely solely on home-based preschool education, most parents send their children at least to kindergarten (Statistisches Bundesamt, 2012).

Hence, in 1996, the government passed a law that grants lawful entitlement to kindergarten access for all children from age three until elementary school. However, the provision of child care has traditionally been a local responsibility of the federal states (Evers, Lewis, \& Riedel 2005). Preschool child care is usually higher in Germany's eastern region because of its close relation with the history of female employment. Because kindergarten costs are regulated on the community level, they differ substantially, often based on number of children and family income. This redistributional approach is designed to promote the use of preschool child care by lowincome families and those needing social assistance, who are entitled to additional public support from youth welfare offices to cover additional expenses like child subsistence costs.

In recent years, however, despite Germany's long kindergarten tradition, the core tasks of preschool child care have shifted away from social and pedagogical care toward early child education. Following the recommendations of the PISA studies and the rising demand for increased female labor force participation, the German government has intensified its efforts to improve and modernize the supply of preschool child care (Hemmerling, 2007). For example, a 2008 law focused on extending Kita placement promised a stepwise expansion of early child day care that would ensure universal coverage by 2013. This legislation, however, failed to meet expectations, and the coverage of available Kita places remains limited. Another new law engendered by regional political pressure provided alternative financial compensation for 
families that chose to raise their children at home in a more traditional family model rather than exercising their lawful right to send them to Kita. This financial compensation, however, was criticized as a misdirected incentive because not only did it not benefit families on social security (Arbeitslosengeld II) but experts worried it would strengthen traditional gender roles and reduce the use of preschool child care by low-income households (Spieß, 2012). Nevertheless, even though the regulation was found unconstitutional and repealed in mid-2015, preschool child care remains a highly debated topic in Germany, with advocates frequently stressing its importance for child development and the ability of early interaction with other children to improve social competencies later in life. The increasing share of migrant families in Germany, particularly, are encouraged to take advantage of publicly offered day care as a means to foster social integration and improve language abilities. The scientific evidence for preschool child care's ability to achieve these goals, however, remains ambiguous. 


\section{Data And Methodology}

Our empirical analysis is based on data from the first wave of German Health Interview and Examination Survey for Children and Adolescents (KiGGS), collected between 2009-2012 by the Robert Koch Institute (http://www.kiggs-studie.de/english/home.html). Designed primarily to gather information on the health status of Germany's youth, this survey offers 17,000 observations of 0 - to 17-year-olds obtained through differently administered questionnaires (e.g., filled out by parents, physicians, or the children themselves; Kurth et al. 2006). Overall the data constitutes a representative cross-section of the German child and adolescent population that also includes household and retrospective information about the child's health and educational history. To permit a more detailed subsample analysis, however, it also oversamples East German and migrant children, an unequal selection probability that we adjust for by using survey weights throughout the analysis.

Our main relation of interest is preschool child care's effect on child well-being, which we approximate by the KiGGS' quality of life sum score ( $y_{i}$ in Equation 1) derived from 24 Likert-scale items in six different dimensional scales (emotional well-being, physical well-being, self-esteem, family, friends, and school) in the parental version of KINDL (Bullinger, Brütt, Erhart, \& Ravens-Sieberer, 2008). Those items are combined and transformed to a one-item sum score range ranging from 0 to 100 . The reliability and validity of this score, one of the few German-language measures of child quality of life, has been verified using several tests (RavensSieberer \& Bullinger, 2000). In the KiGGS data set, parental information on the sum score is available for ages 3 to 17 , which reduces the sample size to fewer than 15,000 observations, with self-assessed values collected only from children aged 10-17. We rely mostly on the values from this parental evaluation because of its larger sample size and demonstrated reliability (Erhart, Ellert, Kurth, \& Ravens-Sieberer, 2009). Nevertheless, we later split the sample by different age 
groups and then take a detailed look at individual subscales of the sum score to identify the impact on different life domains.

As an explanatory variable, we focus primarily on the experience of child care. For the main analysis, we use a child care dummy equal to $1\left(d_{i}=1\right)$ if child $i$ has experienced any type of preschool child care (e.g., Kita and/or kindergarten) and $0\left(d_{i}=0\right)$ if the child has been raised exclusively in the family household. Our second main variable of interest is a dummy for being a migrant $\left(m_{i}\right)$. According to the KiGGS definition, migrants are defined as either (1) a child born in a foreign country with at least one non-German parent $\left(m_{i}=1\right)$ or $(2)$ a child with two non-German parents. Children born in Germany with only one non-German parent are not considered as migrants $\left(m_{i}=0\right)$ (see Schenk et al. (2007) for further details). For simplification we refer to these children as migrant children, although some of those children might be better described as children with a migrant background.

To identify the relation between preschool child care and child well-being, we rely on the following equation estimated by OLS and 2SLS:

$$
y_{i}=x_{i} \beta+\gamma d_{i}+\delta m_{i}+\rho\left(d_{i} \times m_{i}\right)+\varepsilon_{i}
$$

To allow for different effects of preschool child care on migrant children, we include an interaction term $\left(d_{i} \times m_{i}\right)$ in some of the regressions. We also address the question of preschool child care starting age by differentiating children who attended Kita from those who began on the kindergarten level (we attribute a starting age under 3 to Kita and one between 3 and 6 to kindergarten). In line with survey administrator suggestions, we cluster the standard errors $\left(\varepsilon_{i}\right)$ on the sample point level. To estimate a causal relationship of child care on well-being one needs to account for all characteristics that might correlate with the uptake of child care and also well- 
being. Selection into child care might differ between different socio-economic status and values. For instance, despite controlling for the need of child care, lower earnings still have a negative impact on uptake in Bulgaria (Meurs, 2006). To account for selection into child care, we rely on a rich set of child, parental, and household covariates that capture differences in socio-economic status and residency, which are captured by the $1 \times(K+1)$ vector $x_{i}$ in Equation 1 (see Table 1 ), with $K$ equal to the number of covariates included in a particular model. We cannot rule out the possibility that selection is based on unobserved characteristics, as our cross-section data do not provide a clearly exogenous variation of child care uptake. However, most recent work studying this phenomenon show that such selection into child care does not constitute the main determinant for different outcomes between children with and without preschool child care experience (Cornelissen et al., 2017; Felfe \& Lalive, 2018).

That accounting for unobserved characteristics can avoid false conclusions was observed by Felfe \& Huber (2017). The benefits for Roma children in social-emotional development estimated with their selection-on-observables approach vanished when using the instrumental variable approach using proximity to child care facilities as an instrument. Even though our data set does not provide a suitable instrument per se, we test the importance of unobserved heterogeneity by implementing an IV-method developed by Lewbel (2012), which we explain in section 6 in more detail.

The separation between children with and without experience of child care (Table 1) indicates that the former tend to come from families with a higher social status and higher employment levels. The statistics also show that the share of migrant children with child care experience is lower than the share of native children. In Figure 1, which separates the share of children formerly or currently in preschool care by migration and social status, all groups show an increasing rate of experience up to the age of kindergarten entry (the socioeconomic categories are based on the Winkler index (Winkler \& Stolzenberg, 1999), which divides society into classes 
based on parental education, occupation, employment, and income). Among German natives, however, the share does not differ by social strata and remains fairly constant for older cohorts. Among migrants, we observe two notable differences: (1) the overall share is lower than for German children and (2) preschool child care experience is lower for older cohorts in the lowest socioeconomic strata. These observations stem from past, albeit declining, selections of low status migrants out of preschool child care. The descriptive statistics in Table 1 show not only that migrant children tend to come from lower socioeconomic backgrounds, but that they tend to live more frequently in large cities (city size is measured as categorical variable according to the number of inhabitants: rural area less than 5,000; small city 5,000 to 20,000; medium sized city $20,000$ to 100,000 ; large city more than 100,000$)$. It is however not possible to identify the geographical areas of origin of the migrants from the data set. According to census data (Statistisches Bundesamt, 2017), the following five countries represent the most frequent origin for children with migrant background aged 0-20: Turkey (22\%), Poland (8\%), Russian Federation (7\%), Italy (4\%) and Kosovo (3\%). On average, migrants also tend to have more behavioral problems (SDQ sum score) and lower well-being, signaled by differences in group means.

\section{*** TABLE 1 ABOUT HERE ***}

\section{*** FIGURE 1 ABOUT HERE ***}

\section{RESUlts}

The relation between child care and well-being is outlined in Table 2, whose first column reports the outcomes for the model without interaction effects. These results, although they do not attain statistical significance, suggest an overall negative impact of preschool care on child well-being. Over all the models, the KINDL sum score diminishes as age rises and is substantially lower for children in nontraditional families, with a notable reduction in well-being when the household 
includes a new partner. On average, children in East Germany and those from richer households show higher levels of well-being.

Column 2 then introduces the interaction term between migrants and preschool child care, which once its different effects on migrants are considered, changes the coefficients and yields a significantly lower level of well-being for migrant children. More specifically, the size of the coefficient is now comparable with that for children from single female parent (vs. two parent) homes. The overall child care coefficient also becomes negative, suggesting that children who experience preschool child care have lower levels of well-being. For migrant children, on the other hand, the opposite seems true: they appear to benefit from this experience. In fact, the highly significant interaction term indicates that migrant children who experience preschool care score nearly 2 sum points higher than their counterparts who remain at home.

When we further divide child care based on age of entry (column 3), the results suggest that in general, children who attend Kita (i.e., experience preschool child care before the age of 3) have lower levels of well-being. The subsequent introduction of the interaction term (column 4) yields results similar to those from the previous model: the experiences of nonmigrants and migrants differ substantially, but the overall effect is significantly negative, with an early start in preschool child care seeming to produce an especially strong reduction in well-being. For migrant children, however, the positive interaction term suggests an overall beneficial relation, with higher levels of well-being among children who attend kindergarten only.

Given the substantial experiential difference between migrants and nonmigrants, in columns 5 and 6, we further investigate the intensive margin. In Sample II, we attempt to determine whether the year that child care is begun affects well-being by excluding all of the children with no experience of preschool child care (which necessarily leads to a lower number of observations). In line with previous results, a higher starting age appears to be associated with 
higher levels of well-being, implying that receiving preschool child care too early has detrimental effects that do not differ significantly between nonmigrant and migrant children.

\section{*** TABLE 2 ABOUT HERE ***}

To identify the different effects on elementary versus secondary school children, Table 3 divides the sample by age group (since our age data use 2-year increments, we include 10-yearolds in the secondary school sample). Because the data are cross-sectional, however, we cannot rule out a possible bias through cohort effects, which cannot be distinguished from child age. For children aged 6 to 9, the results in column 1 reveal no differences in well-being based on either child care or being a migrant, but, as in the full sample, those in column 2 indicate that wellbeing among migrant children in elementary school (Sample I) varies greatly depending on early child care experience. Whereas the well-being of migrant children is nearly 5 sum score points lower overall than that of nonmigrant children, this difference is nullified when they have experienced preschool child care. Breaking the sample down by the type of child care in columns 3 and 4 suggests that experiencing kindergarten only is slightly more valuable for well-being than experiencing early child care. For the older children, we find less heterogeneity between nonmigrant and migrant children but still observe a significantly negative coefficient for child care overall; particularly, for kindergarten only.

In Table 4, we attempt to identify which well-being domains are most affected by the child care experience based on the six different subscales that make up the KINDL sum score. We again control for possible heterogeneity among age groups by splitting the sample into elementary and secondary school children. For physical well-being (column 1), the coefficient of the migrant dummy is only significant for elementary school children (panel B). In this 
domain, migrant children score over 5 points less than nonmigrants, although this difference is more than offset for those who have experienced child care.

*** TABLE 3 ABOUT HERE ***

*** TABLE 4 ABOUT HERE ***

In line with the total KINDL sum score, psychological well-being is lower for migrants and and nonmigrant children in child care (panel A), a more pronounced difference emerges for migrants in the sample of elementary school children (panel B). Self-esteem, on the other hand, shows a long term effect in migrant children with experience of care, with a strong positive interaction term among secondary school children (panel C). For the family domain, child care experience seems slightly detrimental for nonmigrant children but differs between panels for migrant children. That is, whereas the full sample yields positive point estimates for the migrant dummy and interaction term, the elementary school age subsample has a 4.7 point higher score related to child care, and the interaction term is insignificant for secondary school children, among whom migrants overall significantly score 3.7 points higher independent of preschool experience. In the friends domain, the coefficients again show the general pattern of child care experience making a strong difference, especially among younger migrants. The school domain, however, shows a systematically lower level for migrant children, one that does not change with child care experience. Overall, however, with a few exceptions, we observe stronger effects for elementary than for secondary school children, which suggests that long term effects are smaller than short term effects.

Finally, we investigate the heterogeneous impact of child care on other child outcomes. Columns 1 and 2, Table 5, for example, show the estimates for the children's self-assessed 
KINDL sum score, which is only available for ages 10 to 17 . In line with the results from the main analysis, (columns 2 and 4, Table 2), migrant children score significantly worse overall, although the effect of child care is positive albeit not statistically significant. The next four columns refer to the SDQ. While the first subscale measures pro-social behavior (higher values indicate more pro-social behavior), the sum score consists of multiple subscales that measure child behavioral problems. As columns 3 and 4 show, German children with early child care experience exhibit slightly less pro-social behavior. The estimates for the overall SDQ sum score (column 5) mimic the well-being regressions. Children with preschool child care experience and migrants show generally higher scores, which deviates from previous results by Datta Gupta \& Simonsen (2010) who only find negative effects among boys from low SES households in family care, but not preschool child care. However, the interaction term in our regression tends to mediate both effects, suggesting that migrants tend to benefit from child care or are at least not negatively affected by it.

*** TABLE 5 ABOUT HERE ***

The estimates in Table 5 reveal only a small and insignificant relation between preschool child care and math and German skills, measured on the local 6-point valuation scheme, whose highest score of 1 means that positive coefficients signal negative outcomes. However, based on the estimates in columns 7 to 8 , all else being equal, migrants perform better overall in math; while child care participation seems to reduce performance later in school. This negative effect for migrant children stems from those that attend kindergarten only. Regarding German skills, we observed insignificant differences between the groups. However, the point estimates for child care participation and migrant children suggest slightly lower German skills. 


\section{ROBUSTNESS}

The issue of selection into child care remains an important concern for the interpretation of our results. Even though we control for a rich set of possible confounding variables and previous research found little evidence for strong selection effects, we cannot rule out the other variable might bias our estimates. Additionally, given the structure of our data set some characteristics are measured several years after the actual children care took place and could hence be affected by the child care decision itself. For instance, if parents drop out of employment because their child cannot cope with the child care experience, parental employment status would be a bad control (Angrist \& Pischke, 2008). To explore the bias of these potentially bad controls and to show the overall effect our large number of control variables, we re-estimate the models presented in Table 2, while only controlling for the age and gender of the child - two clearly exogenous covariates.

The results provided in Table 6 show that our findings remain mainly unchanged, with few noteworthy differences: first, the large number of covariates in Table 2 is associated with missing values that increase the sample size and statistical power of these unconditional models. This might explain the negative and significant coefficient of child care in column 1. Second, without adjusting for socio-demographic characteristics, children with a migrant background show lower well-being overall. However, coefficients of the child care and their interactions remain similar. Third, among the children experiencing child care (sample II) starting age is no longer statistically significant and migrant children do not show a higher level of well-being. Based on these results, we reject the presumption that our main findings are strongly affected by using covariates that might be so-called bad controls and we additionally conclude that selection, at least on observable characteristics, seems not to be a major issue for our analysis.

To address selection on unobserved characteristics we additionally implement the Lewbel 2-stage least squares estimator. This estimator can be used for identification when clear exogenous variation is not available, i.e. if identification via standard IV methods is unfeasible 
due to the missing of exogenous instruments. For such cases, Lewbel (2012) shows that identification can still be attained if the data set at hand is characterized by a sufficient amount of heteroskedasticity, which can be used to generate exogenous instruments. Specifically, this means that our model can modified in the following way to obtain identification:

Consider the following system of equations,

$$
\begin{array}{cr}
y_{i}=x_{i} \beta+\gamma d_{i}+\delta m_{i}+\rho\left(d_{i} \times m_{i}\right)+\varepsilon_{i} & \varepsilon_{i}=\alpha U_{i}+V_{i} \\
d_{i}=x_{i} \beta+\delta m_{i}+u_{i} & u_{i}=\theta U_{i}+W_{i}
\end{array}
$$

with $U_{i}$ being some unobserved characteristic that may lead to selection into child care (i.e., if $\operatorname{cov}(d, U) \neq 0$ and $\operatorname{cov}(y, U) \neq 0$ while $\gamma \neq 0) .{ }^{1}$ However, if we assume that the subsequent conditions hold (which are the standard assumptions, required for an estimator to be consistent),

$$
E(x \varepsilon)=0, E(x u)=0, E(m \varepsilon)=0, E(m u)=0, \operatorname{cov}(x, \varepsilon u)=0, \operatorname{cov}(m, \varepsilon u)=0
$$

and that the errors in Equation (3) are heteroskedastic, Lewbel's method allows us to construct the $K$ exogenous instruments $z$ that have the following form:

$$
\begin{aligned}
& z_{i, k}=\left(x_{i, k}-\bar{x}_{k}\right) u_{i}, \quad k \in\{1, \ldots, K-1\} \\
& z_{i, k+1}=\left(m_{i}-\bar{m}\right) u_{i}
\end{aligned}
$$

The underlying idea is that heteroskedasticity within the data leads to moments of higher order of $u$ which are functional forms of the exogenous explanatory variable, i.e. that $\operatorname{cov}\left(x, u^{2}\right) \neq 0$ and/or $\operatorname{cov}\left(m, u^{2}\right) \neq 0$. The heteroskedasticity can then be exploited to explain variance in $d$ by construction of the valid instrument $z$ as shown in Equation (5) and (6). In order to estimate a fully identified model by 2SLS, the endogenous variable $d$ in Equation (2) is then replaced by $\hat{d}$,

\footnotetext{
${ }^{1}$ Characteristics that lead to selection could be, for instance, social emotional outcomes such as self-confidence and/or peer-relations (as suggested by Felfe and Lalive (2018), who find selection into child-care to be driven by these outcomes).
} 
which is the predicted value for $d$ of a first stage regression of $d$ on $x, m$ and $z$. A detailed description and proofs of the underlying theorem can be found in Lewbel (2012). Related to the application in this paper, Lewbel (2018) argues for the general applicability of this method to binary endogenous regressors, but also highlights that the underlying assumptions are not as straightforward as in the case where the variable of interest is continuous.

The results of this approach are shown in Table 7, where we re-estimate our main model (Table 2). As there are only minor changes in both, the point estimates as well as the level of significance of the estimated coefficients, we conclude that selection into child-care based on unobservable characteristics is no (or at least a minor) issue in our sample. ${ }^{2}$

\section{CONCLuSions}

In analyzing the relation between preschool child care and child well-being, as well as other child outcomes, we focus particularly on a possible heterogeneous experience for migrants. Overall, our results suggest that child care experience is associated with a slightly lower level in child well-being, with some evidence on the intensive margin that more years of preschool child care attendance reduce overall well-being. Although in general our findings support the existing literature (Belsky, 2006; Loeb et al., 2007; Magnuson et al., 2007), they differ in their focus on well-being as the primary measure for potential child care effects rather than the well-established child outcome variables such as cognitive skills (e.g., math or language scores) or amount of externalizing behavior. We are therefore able to make a valuable contribution to the knowledge gap on the relationship between well-being and early preschool child care. Of particular interest

\footnotetext{
${ }^{2}$ Since the relevance of the constructed instruments rely highly on the degree of heteroskedasticity within the data, it might be the case that our 2SLS estimates suffer from a weak identification issue. To test this hypothesis, we compute the Wald F-statistic of the respective first-stage regression, which, in fact, shows no sign of weak identification.
} 
is our finding of higher well-being levels among migrant children, particularly those of elementary school age. Those findings are in line with recent results on the effect of preschool child care on school readiness in Germany (Cornelissen et al., 2017; Felfe \& Lalive, 2018). Even though we cannot fully rule out selection into child care based on unobservable characteristics that positively affect well-being measures, the mostly positive experience for migrant children emphasizes the importance of preschool child care for more than mere school success. These findings are also supported by the results of the IV estimates, which yield no evidence for selection on unobservables. Another potential limitation is the lack of detailed data about the composition of the family members involved in home care. A larger and supportive family network among non-migrant children compared to families with migration background might contribute to observed differences.

Seemingly, for children with a migratory background, not participating in preschool child care is associated with substantially lower levels of well-being. One possible explanation for this positive relationship with preschool child care (reflected by the large coefficients in columns 4 and 5, Table 2) may be that migrants with no preschool care experience enter compulsory elementary education without any familiarity with public education facilities, leading them to have more problems adapting to the new environment. Nonetheless, although this supposition is supported by the lack of evidence for a long term child care effect on the well-being of migrant children, it is contradicted by the persistently lower scores on the KINDL subscale for school readiness (column 6, Table 4). The math and language skill results also raise questions about preschool child care's ability to increase the school readiness of migrant children in Germany.

Rather, the analyses of the single domain KINDL sum scores suggest that well-being is more driven by a social component. For example, the measures for psychological well-being and friends are significantly higher for both the full sample and both subsamples (elementary and secondary school), suggesting a long term benefit that might be able to explain higher graduation 
rates (see Havnes \& Mogstad 2015), which could ultimately translate into higher earnings. Likewise, self-esteem tends to be systematically lower among migrant than nonmigrant children. An additional analysis of the SDQ sum score, which measures child behavioral problems, supports this pattern. Whereas overall preschool child care seems to be associated with more behavioral problems, migrant children seem unaffected. We also identify a negative association between child care and migrant children's math performance even though early child care seems to have not statistically significant effect on math and German skills in the total sample.

The differences we observe between migrants and nonmigrants make it difficult to extrapolate general policy implications. Nevertheless, the negative outcomes for German children, although rather small, raise questions about the implementation of mandatory kindergarten laws. In fact, our results indicate that even if children would benefit in cognitive skills through early child care (i.e. Kita), for which our study provides little evidence, they show the strongest decline in well-being. An observation that requires particular attention given the recent shift in preschool child care toward more educative goals, which might reduce the focus on non-cognitive factors such as well-being.

The results of our analysis also emphasize that migrant children who experience no preschool child care are much worse off than their German native counterparts in terms of the KINDL and most other scores. Hence, promoting preschool child care for migrant children might increase their overall well-being. Such promotion might take the form of information campaigns especially targeted at migrant families that explain the potential benefits of preschool child care and highlight the opportunities migrant children would miss by not attending. 


\section{REFERENCES}

Angrist, J. D. \& Pischke, J. S. (2008). Mostly Harmless Econometrics: An Empiricist's Companion. Princeton University Press

Baum, C.F. \& Schaffer, M.E. (2012). IVREG2H: Stata module to perform instrumental variables estimation using heteroskedasticity-based instruments. In: Statistical Software Components S457555. Boston College Department of Economics.

Belsky, J. (2006). Early child care and early child development: Major findings of the NICHD study of early child care. European Journal of Developmental Psychology, 3(1), 95-110. doi:10.1080/17405620600557755

Blau, D. M. (1999). The effect of pregnancy intention on child development. The Journal of Human Resources, 34(4), 786-822. doi:10.2307/2648098

Bullinger, M., Brütt, A. L., Erhart, M., \& Ravens-Sieberer, U. (2008). Psychometric properties of the KINDL-R questionnaire: Results of the BELLA study. European Child and Adolescent Psychiatry, 17(SUPPL. 1), 125-132. doi:10.1007/s00787-008-1014-z

Bundesamt, S. (2012). Kindertages- betreuung in Deutschland 2012 Kindertages- betreuung in Deutschland 2012, (November).

Burger, K. (2010). How does early childhood care and education affect cognitive development? An international review of the effects of early interventions for children from different social backgrounds. Early Childhood Research Quarterly, 25(2), 140-165. doi:10.1016/j.ecresq.2009.11.001

Care, E. C., \& Development, C. (2002). Early Child Care and Children's Development Prior to School Entry: Results from the NICHD Study of Early Child Care. American Educational Research Journal, 39(1), 133-164. doi:10.3102/00028312039001133 
Crosnoe, R. (2007). Early child care and the school readiness of children from Mexican immigrant families. International Migration Review, 41(1), 152-181. doi:10.1111/j.17477379.2007.00060.x

Cryan, J. R., Sheehan, R., Wiechel, J., \& Bandy-Hedden, I. G. (1992). Success outcomes of fullday kindergarten: More positive behavior and increased achievement in the years after. Early Childhood Research Quarterly, 7(2), 187-203. doi:10.1016/0885-2006(92)90004-I

Datta Gupta, N., \& Simonsen, M. (2010). Non-cognitive child outcomes and universal high quality child care. Journal of Public Economics, 94(1-2), 30-43. doi:10.1016/j.jpubeco.2009.10.001

Dhuey, E. (2011). Who Benefits From Kindergarten? Evidence From the Introduction of State Subsidization. Educational Evaluation and Policy Analysis, 33(1), 3-22. doi:10.3102/0162373711398125

Driessen, G. W. J. M. (2004). A large-scale longitudinal study of the utilization and effects of early childhood education and care in The Netherlands. Early Child Development and Care, 174(7-8), 667-689. doi:10.1080/0300443042000187158

Cornelissen, T., Dustmann, C., Raute, A., \& Schönberg, U. (2017). Who benefits from universal child care? Estimating marginal returns to early child care attendance. Journal of Political Economy, forthcoming.

Erhart, M., Ellert, U., Kurth, B.-M., \& Ravens-Sieberer, U. (2009). Measuring adolescents' HRQoL via self reports and parent proxy reports: an evaluation of the psychometric properties of both versions of the KINDL-R instrument. Health and Quality of Life Outcomes, 7, 77. doi:10.1186/1477-7525-7-77

Evers, A., Lewis, J., \& Riedel, B. (2005). Developing child-care provision in England and 
Germany: problems of governance. Journal of European Social Policy, 15(3), 195-209. doi.org/10.1177/0958928705054082

Felfe, C., Nollenberger, N., \& Rodríguez-Planas, N. (2015). Can’t buy mommy’s love? Universal childcare and children's long-term cognitive development. Journal of Population Economics, 28(2), 393-422. http://doi.org/10.1007/s00148-014-0532-x

Felfe, C., \& Huber, M. (2017). Does preschool boost the development of minority children?: the case of Roma children. Journal of the Royal Statistical Society. Series A: Statistics in Society, 180(2), 475-502. http://doi.org/10.1111/rssa.12207

Felfe, C., \& Lalive, R. (2018). Does Early Child Care Help or Hurt Children's Development? Journal of Public Economics, forthcoming.

Havnes, B. T., \& Mogstad, M. (2011). No Child Left Behind: Subsidized Child Care and Children's Long-Run Outcomes. American Economic Journal: Economic Policy, 3(2), 97129. doi:10.1257/pol.3.2.97

Havnes, T., \& Mogstad, M. (2015). Is universal child care leveling the playing field? Journal of Public Economics, 127, 100-114. http://doi.org/10.1016/j.jpubeco.2014.04.007

Hemmerling, A. (2007). Der Kindergarten als Bildungsinstitution. Verlag für Sozialwissenschaften.

Kurth, B., Kamtsiuris, P., Hölling, H., Schlaud, M., Dölle, R., Ellert, U., ... Wolf, U. (2006). The challenge of comprehensively mapping children $\hat{a} €^{\mathrm{TM}} \mathrm{s}$ health in a nation-wide health survey : Design of the German KiGGS-Study, 8, 1-8. doi:10.1186/1471-2458-8-196

Lewbel, A. (2012). Using heteroscedasticity to identify and estimate mismeasured and endogenous regressor models. Journal of Business \& Economic Statistics, 30(1), 67-80. https://doi.org/10.1080/07350015.2012.643126 
Lewbel, A. (2018). Identification and estimation using heteroscedasticity without instruments: The binary endogenous regressor case. Economics Letters, 165, 10-12. https://doi.org/10.1016/j.econlet.2018.01.003

Loeb, S., Bridges, M., Bassok, D., Fuller, B., \& Rumberger, R. W. (2007). How much is too much? The influence of preschool centers on children's social and cognitive development. Economics of Education Review, 26(1), 52-66. doi:10.1016/j.econedurev.2005.11.005

Magnuson, K. a., Ruhm, C., \& Waldfogel, J. (2007). Does prekindergarten improve school preparation and performance? Economics of Education Review, 26(1), 33-51. doi:10.1016/j.econedurev.2005.09.008

Magnuson, K., Lahaie, C., \& Waldfogel, J. (2006). Preschool and School Readiness of Children of Immigrants. Social Science Quarterly, 87(5), 1241-1262. doi:10.1111/j.15406237.2006.00426.x

Meurs, M. (2006). Decline in pre-school use in post-socialist societies: the case of Bulgaria. Journal of European Social Policy, 16(2), 155-166. doi:10.1177/0958928706062504

Network, N. I. of C. H. and H. D. E. C. C. R. (2003). Does amount of time spent in child care predict socioemotional adjustment during the transition to kindergarten? Child Development, 74(4), 976-1005. doi:10.1111/1467-8624.00582

NICHD Early Child Care Research Network. (2001). Nonmaternal care and family factors in early development: An overview of the NICHD Study of Early Child Care. Journal of Applied Developmental Psychology, 22(5), 457-492. doi:10.1016/S0193-3973(01)00092-2

NICHD Early Child Care ResearchNetwork. (2004). Type of child care and children's development at 54 months. Early Childhood Research Quarterly, 19(2), 203-230. doi:10.1016/j.ecresq.2004.04.002 
Obeng, C. S. (2007). Immigrants Families and Childcare Preferences: Do Immigrants' Cultures Influence Their Childcare Decisions? Early Childhood Education Journal, 34(4), 259-264. doi:10.1007/s10643-006-0132-9

Peisner-Feinberg, E. S., Burchinal, M. R., Clifford, R. M., Culkin, M. L., Howes, C., Kagan, S. L., \& Yazejian, N. (2001). The relation of preschool child-care quality to children's cognitive and social developmental trajectories through second grade. Child Development, 72(5), 1534-1553. doi:10.1111/1467-8624.00364

Ravens-Sieberer, U., \& Bullinger, M. (2000). KINDL R English Manual. Questionnaire for Measuring Health-Related Quality of Life in Children and Adolescents Revised Version. KINDL, Germany.

Schenk, L., Ellert, U., \& Neuhauser, H. (2007). Children and adolescents in Germany with a migration background. Methodical aspects in the German Health Interview and Examination Survey for Children and Adolescents (KiGGS). Bundesgesundheitsblatt, Gesundheitsforschung, Gesundheitsschutz, 50(5-6), 590-599.

Schlack, R., Hölling, H., \& Kurth, B. M. (2007). Inanspruchnahme außerfamiliärer vorschulischer Kindertagesbetreuung und Einfluss auf Merkmale psychischer Gesundheit bei Kindern. Bundesgesundheitsblatt-Gesundheitsforschung-Gesundheitsschutz, 50(10), $1249-1258$.

Schober, P. S., \& Schmitt, C. (2017). Day-care availability, maternal employment, and satisfaction of parents: Evidence from cultural and policy variations in Germany. Journal of European Social Policy. doi:10.1177/0958928716688264

Spieß, C. K. (2012). Betreuungsgeld widerspricht den Zielen nachhaltiger Familienpolitik. DIWWochenbericht, $79(24)$. 
Spiess, C. K., Büchel, F., \& Wagner, G. G. (2003). Children's school placement in germany: Does Kindergarten attendance matter? Early Childhood Research Quarterly, 18(2), 255-270. doi:10.1016/S0885-2006(03)00023-1

Statistisches Bundesamt (2012). Kindertagesbetreuung in Deutschland 2012.

Statistisches Bundesamt (2017). Bevölkerung mit Migrationshintergrund - Ergebnisse des Mikrozensus 2010.

Turney, K., \& Kao, G. (2009). Pre-kindergarten child care and behavioral outcomes among children of immigrants. Early Childhood Research Quarterly, 24(4), 432-444. doi:10.1016/j.ecresq.2009.07.007

Vandell, D. L., Belsky, J., Burchinal, M., Steinberg, L., \& Vandergrift, N. (2010). Do Effects of early child care extend to age 15 years? Results from the nichd study of early child care and youth development. Child Development, 81(3), 737-756. doi:10.1111/j.14678624.2010.01431.x

Votruba-Drzal, E., Li-Grining, C. P., \& Maldonado-Carreo, C. (2008). A Developmental Perspective on Full- Versus Part-Day Kindergarten and Childrens Academic Trajectories Through Fifth Grade. Child Development, 79(4), 957-978. doi:10.1111/j.14678624.2008.01170.x

Winkler, J., \& Stolzenberg, H. (1999). Der Sozialschichtindex im Bundes-Gesundheitssurvey. Thieme. 
Tables and Figures

Table 1. Descriptive statistics

\begin{tabular}{|c|c|c|c|c|c|}
\hline & Full & $\begin{array}{l}\text { Child } \\
\text { care }\end{array}$ & Home care & Nonmigrant & Migrant \\
\hline Child age (years) ${ }^{a}$ & 10.203 & 10.249 & $9.954 * *$ & 10.195 & 10.258 \\
\hline Child male ${ }^{\mathrm{b}}$ & 0.513 & 0.516 & 0.494 & 0.513 & 0.515 \\
\hline Parents single ${ }^{b}$ & 0.043 & 0.044 & 0.040 & 0.043 & 0.042 \\
\hline More than 4 Persons in $\mathrm{HH}^{\mathrm{b}}$ & 0.302 & 0.294 & $0.342 * * *$ & 0.287 & $0.408 * * *$ \\
\hline Sibling in $\mathrm{HH}^{\mathrm{b}}$ & 0.823 & 0.815 & $0.862 * * *$ & 0.817 & $0.861 * * *$ \\
\hline Social category ${ }^{\mathrm{a}}$ & 12.213 & 12.338 & $11.540 * * *$ & 12.589 & $9.607 * * *$ \\
\hline \multicolumn{6}{|l|}{ Father } \\
\hline Vocational training ${ }^{\mathrm{b}}$ & 0.269 & 0.267 & 0.282 & 0.264 & $0.305 * * *$ \\
\hline University degree $^{b}$ & 0.255 & 0.261 & $0.224 * * *$ & 0.269 & $0.162 * * *$ \\
\hline Part-time job ${ }^{b}$ & 0.027 & 0.028 & $0.020 * *$ & 0.025 & $0.038 * *$ \\
\hline Full-time job ${ }^{b}$ & 0.895 & 0.896 & 0.888 & 0.910 & $0.788 * * *$ \\
\hline Self-employed ${ }^{\mathrm{b}}$ & 0.141 & 0.142 & 0.137 & 0.148 & $0.093 * * *$ \\
\hline Age (group) $)^{\mathrm{a}}$ & 5.003 & 5.000 & 5.017 & 5.050 & $4.677 * * *$ \\
\hline \multicolumn{6}{|l|}{ Mother } \\
\hline Vocational training ${ }^{\mathrm{b}}$ & 0.278 & 0.281 & 0.263 & 0.281 & 0.263 \\
\hline University degree $^{\mathrm{b}}$ & 0.164 & 0.175 & $0.107 * * *$ & 0.165 & 0.159 \\
\hline Part-time job ${ }^{\mathrm{b}}$ & 0.497 & 0.499 & 0.485 & 0.520 & $0.332 * * *$ \\
\hline Full-time job ${ }^{b}$ & 0.181 & 0.195 & $0.100 * * *$ & 0.176 & $0.211^{* *}$ \\
\hline Self-employed ${ }^{\mathrm{b}}$ & 0.064 & 0.068 & $0.043 * * *$ & 0.067 & $0.044 * * *$ \\
\hline Age (group) ${ }^{\mathrm{a}}$ & 4.440 & 4.444 & 4.420 & 4.502 & $4.010^{* * *}$ \\
\hline East Germany ${ }^{\mathrm{b}}$ & 0.161 & 0.181 & $0.057 * * *$ & 0.175 & $0.068 * * *$ \\
\hline Rural areab $^{\mathrm{b}}$ & 0.195 & 0.193 & 0.200 & 0.215 & $0.055 * * *$ \\
\hline Small city ${ }^{\mathrm{b}}$ & 0.286 & 0.285 & 0.294 & 0.298 & $0.208 * * *$ \\
\hline Medium sized city ${ }^{\mathrm{b}}$ & 0.294 & 0.291 & 0.313 & 0.288 & $0.342 * * *$ \\
\hline Large city ${ }^{\mathrm{b}}$ & 0.225 & 0.230 & $0.193 * * *$ & 0.200 & $0.395 * * *$ \\
\hline Net HH income (grouped) $)^{\mathrm{a}}$ & 8.984 & 9.031 & $8.731 * * *$ & 9.197 & $7.507 * * *$ \\
\hline SDQ sum score ${ }^{\mathrm{a}}$ & 7.837 & 7.889 & $7.553 * *$ & 7.666 & 9.021 \\
\hline KINDL sum score ${ }^{a}$ & 77.271 & 77.176 & $77.785 * *$ & 77.335 & 76.830 \\
\hline Migrant $^{\mathrm{b}}$ & 0.126 & 0.118 & $0.170 * *$ & 0.000 & 1.000 \\
\hline Child care $^{\mathrm{b}}$ & 0.844 & 1.000 & 0.000 & 0.851 & $0.790 * * *$ \\
\hline Observations & 10,814 & 9,358 & 1,456 & 9,650 & 1,164 \\
\hline
\end{tabular}

${ }^{\mathrm{a}}$ Group specific average values.

${ }^{\mathrm{b}}$ Group specific average values. Percentages expressed in decimal numbers were 1.0 reflect $100 \%$.

Notes: Parental age grouped in 5 year brackets starting below 25 to above 55. Household income groups are measured as increasing brackets ranging from 250 to $1000 €$. Differences in means between the two subgroups are indicated by $* \mathrm{p}<.1, * * \mathrm{p}<.05, * * * \mathrm{p}<.01$. 


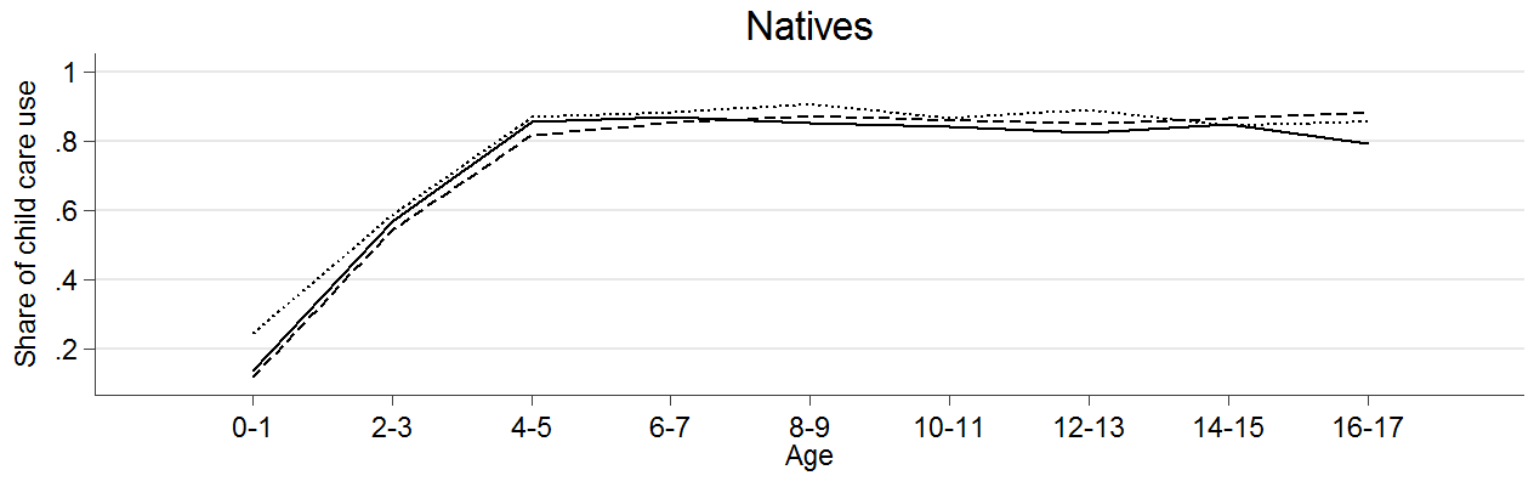

Social class 1

Social class 2

Social class 3

Migrants

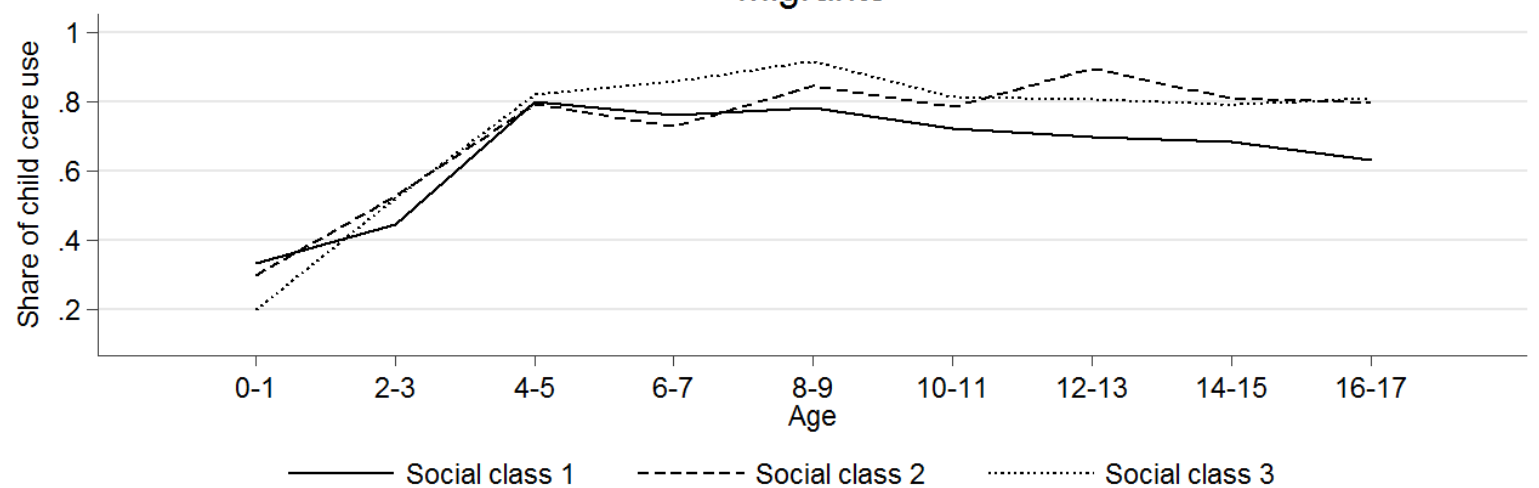

FIGURE 1 PRESCHOOL CHILD CARE PARTICIPATION OF NATIVES AND MIGRANTS BY SOCIAL

STATUS 
Table 2. OLS estimates for the KINDL child well-being measure for children 3-17

\begin{tabular}{|c|c|c|c|c|c|c|}
\hline & \multicolumn{6}{|c|}{ OLS estimates for child well-being measured by the KINDL sum score } \\
\hline & \multicolumn{4}{|c|}{ Sample I } & \multicolumn{2}{|c|}{ Sample II } \\
\hline & $(1)$ & $(2)$ & $(3)$ & (4) & $(5)$ & $(6)$ \\
\hline Child care & $\begin{array}{r}-0.5198 \\
(0.338)\end{array}$ & $\begin{array}{c}\text { ild stayed at } \\
-0.9855^{* * * *} \\
(0.368)\end{array}$ & ne as referer & & & \\
\hline Kindergarten & & & $\begin{array}{c}-0.4296 \\
(0.344)\end{array}$ & $\begin{array}{c}-0.8760^{* *} \\
(0.375)\end{array}$ & & \\
\hline Kita & & & $-0.8723^{* *}$ & $-1.2689^{* * * *}$ & & \\
\hline & & & $(0.398)$ & $(0.425)$ & & \\
\hline Starting age of care & & & & & $\begin{array}{l}0.2361^{*} \\
(0.125)\end{array}$ & $\begin{array}{l}0.2042 \\
(0.130)\end{array}$ \\
\hline Child care*Migrant & & $\begin{array}{c}2.8998^{* * * *} \\
(0.806)\end{array}$ & & & & \\
\hline Kindergarten*Migrant & & & & $\begin{array}{c}2.8614^{* * * *} \\
(0.834)\end{array}$ & & \\
\hline Kita*Migrant & & & & $\begin{array}{c}2.5951^{* * *} \\
(1.093)\end{array}$ & & \\
\hline Starting age*Migrant & & & & & & $\begin{array}{l}0.2729 \\
(0.380)\end{array}$ \\
\hline Migrant & $\begin{array}{l}0.5592 \\
(0.364)\end{array}$ & $\begin{array}{c}-1.7922^{* * *} \\
(0.760)\end{array}$ & $\begin{array}{c}0.6389^{*} \\
(0.369)\end{array}$ & $\begin{array}{c}-1.5954^{* *} \\
(0.770)\end{array}$ & $\begin{array}{c}1.3471^{* * * *} \\
(0.398)\end{array}$ & $\begin{array}{l}0.5022 \\
(1.206)\end{array}$ \\
\hline Age & $\begin{array}{c}-1.3119^{* * * *} \\
(0.058)\end{array}$ & $\begin{array}{c}-1.3101^{* * * *} \\
(0.058)\end{array}$ & $\begin{array}{c}-1.3133^{* * * *} \\
(0.058)\end{array}$ & $\begin{array}{c}-1.3104^{* * * *} \\
(0.058)\end{array}$ & $\begin{array}{c}-1.3535^{* * *} \\
(0.070)\end{array}$ & $\begin{array}{c}-1.3549^{* * * *} \\
(0.071)\end{array}$ \\
\hline Male & $\begin{array}{c}-0.3056 \\
(0.201)\end{array}$ & $\begin{array}{c}-0.2926 \\
(0.201)\end{array}$ & $\begin{array}{c}-0.3229 \\
(0.203)\end{array}$ & $\begin{array}{c}-0.3119 \\
(0.203)\end{array}$ & $\begin{array}{c}-0.3676 \\
(0.226)\end{array}$ & $\begin{array}{c}-0.3688 \\
(0.226)\end{array}$ \\
\hline Sibling in $\mathrm{HH}$ & $\begin{array}{c}-0.0859 \\
(0.735)\end{array}$ & $\begin{array}{c}-0.0912 \\
(0.744)\end{array}$ & $\begin{array}{c}-0.1920 \\
(0.761)\end{array}$ & $\begin{array}{c}-0.2005 \\
(0.771)\end{array}$ & $\begin{array}{l}0.8027 \\
(0.719)\end{array}$ & $\begin{array}{l}0.8027 \\
(0.719)\end{array}$ \\
\hline Net income $\mathrm{HH}$ & $\begin{array}{c}0.2791^{* * * *} \\
(0.054)\end{array}$ & $\begin{array}{c}0.2760^{* * * *} \\
(0.054)\end{array}$ & $\begin{array}{c}0.2880^{* * * *} \\
(0.055)\end{array}$ & $\begin{array}{c}0.2836^{* * * *} \\
(0.055)\end{array}$ & $\begin{array}{c}0.2905^{* * *} \\
(0.062)\end{array}$ & $\begin{array}{c}0.2899^{* * * *} \\
(0.062)\end{array}$ \\
\hline Parental situation & & Parent & arried and $l$ & g together $a$ & erence & \\
\hline Mother with partner & $\begin{array}{c}-1.7939^{* * *} \\
(0.520)\end{array}$ & $\begin{array}{c}-1.8062^{* * * *} \\
(0.521)\end{array}$ & $\begin{array}{c}-1.7512^{* * * *} \\
(0.518)\end{array}$ & $\begin{array}{c}-1.7708^{* * * * *} \\
(0.519)\end{array}$ & $\begin{array}{c}-1.7074^{* * * *} \\
(0.541)\end{array}$ & $\begin{array}{c}-1.7106^{* * * *} \\
(0.541)\end{array}$ \\
\hline Father with partner & $\begin{array}{c}-5.2867^{* * * *} \\
(1.796)\end{array}$ & $\begin{array}{c}-5.2579^{* * * *} \\
(1.794)\end{array}$ & $\begin{array}{c}-5.4407^{* * * *} \\
(1.807)\end{array}$ & $\begin{array}{c}-5.4115^{* * *} \\
(1.806)\end{array}$ & $\begin{array}{c}-5.4071^{* * * *} \\
(1.966)\end{array}$ & $\begin{array}{c}-5.4002^{* * * *} \\
(1.966)\end{array}$ \\
\hline Single mother & $\begin{array}{c}-1.3797^{*} \\
(0.827)\end{array}$ & $\begin{array}{c}-1.4382^{*} \\
(0.828)\end{array}$ & $\begin{array}{c}-1.4544^{*} \\
(0.854)\end{array}$ & $\begin{array}{r}-1.5144^{*} \\
(0.856)\end{array}$ & $\begin{array}{c}-2.3650^{* *} \\
(0.936)\end{array}$ & $\begin{array}{c}-2.3613^{* *} \\
(0.936)\end{array}$ \\
\hline Single father & $\begin{array}{c}-0.2611 \\
(1.381)\end{array}$ & $\begin{array}{c}-0.3108 \\
(1.390)\end{array}$ & $\begin{array}{c}-0.0664 \\
(1.419)\end{array}$ & $\begin{array}{r}-0.1087 \\
(1.427)\end{array}$ & $\begin{array}{c}-0.7054 \\
(1.682)\end{array}$ & $\begin{array}{c}-0.6974 \\
(1.682)\end{array}$ \\
\hline Other & $\begin{array}{c}-3.8431^{* * * *} \\
(1.251)\end{array}$ & $\begin{array}{c}-3.8903^{* * * *} \\
(1.255)\end{array}$ & $\begin{array}{c}-4.2007^{* * *} \\
(1.276)\end{array}$ & $\begin{array}{c}-4.2504^{* * * *} \\
\quad(1.282)\end{array}$ & $\begin{array}{c}-3.9998^{* * * *} \\
(1.356)\end{array}$ & $\begin{array}{c}-4.0173^{* * * *} \\
(1.357)\end{array}$ \\
\hline Type of region & & & Rural are & s a reference & & \\
\hline Small city & $\begin{array}{c}-0.4288 \\
(0.322)\end{array}$ & $\begin{array}{c}-0.4214 \\
(0.319)\end{array}$ & $\begin{array}{r}-0.3771 \\
(0.320)\end{array}$ & $\begin{array}{c}-0.3704 \\
(0.317)\end{array}$ & $\begin{array}{c}-0.2096 \\
(0.393)\end{array}$ & $\begin{array}{r}-0.2115 \\
(0.394)\end{array}$ \\
\hline Medium city & $\begin{array}{c}-0.0762 \\
(0.342)\end{array}$ & $\begin{array}{l}-0.0542 \\
(0.339)\end{array}$ & $\begin{array}{c}-0.0722 \\
(0.339)\end{array}$ & $\begin{array}{c}-0.0538 \\
(0.335)\end{array}$ & $\begin{array}{r}-0.0657 \\
(0.399)\end{array}$ & $\begin{array}{c}-0.0718 \\
(0.400)\end{array}$ \\
\hline Large city & $\begin{array}{c}-0.1450 \\
(0.355)\end{array}$ & $\begin{array}{c}-0.1526 \\
(0.351)\end{array}$ & $\begin{array}{l}-0.1221 \\
(0.363)\end{array}$ & $\begin{array}{r}-0.1315 \\
(0.359)\end{array}$ & $\begin{array}{c}-0.2564 \\
(0.408)\end{array}$ & $\begin{array}{c}-0.2638 \\
(0.408)\end{array}$ \\
\hline East Germany & $\begin{array}{c}1.5645^{* * * *} \\
(0.300)\end{array}$ & $\begin{array}{c}1.6266^{* * * *} \\
(0.300)\end{array}$ & $\begin{array}{c}1.8035^{* * *} \\
(0.327)\end{array}$ & $\begin{array}{c}1.8419^{* * * *} \\
(0.328)\end{array}$ & $\begin{array}{c}1.8930^{* * * *} \\
(0.350)\end{array}$ & $\begin{array}{c}1.8674^{* * * *} \\
(0.353)\end{array}$ \\
\hline $\mathrm{c}$ & $\begin{array}{c}81.5713^{* * *} \\
(1.271)\end{array}$ & $\begin{array}{c}82.1541^{* * * *} \\
(1.299)\end{array}$ & $\begin{array}{c}81.4647^{* * * *} \\
(1.343)\end{array}$ & $\begin{array}{c}82.0426^{* * * *} \\
(1.375)\end{array}$ & $\begin{array}{c}80.5753^{* * * *} \\
(1.565)\end{array}$ & $\begin{array}{c}80.6338^{* * * *} \\
(1.567)\end{array}$ \\
\hline$N$ & 10835 & 10835 & 10536 & 10536 & 9088 & 9088 \\
\hline Adj. $R^{2}$ & 0.083 & 0.085 & 0.084 & 0.085 & 0.086 & 0.086 \\
\hline
\end{tabular}


Table 3. Child well-being split by age group

OLS estimates for child well-being measured by the KINDL sum score

\begin{tabular}{|c|c|c|c|c|c|c|c|c|c|c|c|c|}
\hline & \multicolumn{6}{|c|}{ Children aged 6 to 9 (elementary school) } & \multicolumn{6}{|c|}{ Children aged 10 to 17 (secondary school) } \\
\hline & \multicolumn{4}{|c|}{ Sample I } & \multicolumn{2}{|c|}{ Sample II } & \multicolumn{4}{|c|}{ Sample I } & \multicolumn{2}{|c|}{ Sample II } \\
\hline & (1) & (2) & (3) & (4) & $(5)$ & (6) & (7) & (8) & (9) & $(10)$ & $(11)$ & $(12)$ \\
\hline & \multicolumn{4}{|c|}{ Child stayed at home as reference } & & & \multicolumn{4}{|c|}{ Child stayed at home as reference } & & \\
\hline Child care & $\begin{array}{l}-0.1601 \\
(0.499)\end{array}$ & $\begin{array}{c}-0.9288^{*} \\
(0.546)\end{array}$ & & & & & $\begin{array}{r}-0.8361^{*} \\
(0.492)\end{array}$ & $\begin{array}{c}-1.1688^{* *} \\
(0.494)\end{array}$ & & & & \\
\hline Kindergarten & & & $\begin{array}{l}0.0558 \\
(0.503)\end{array}$ & $\begin{array}{l}-0.7110 \\
(0.549)\end{array}$ & & & & & $\begin{array}{c}-0.8441^{*} \\
(0.501)\end{array}$ & $\begin{array}{c}-1.1483^{* *} \\
(0.504)\end{array}$ & & \\
\hline Kita & & & $\begin{array}{l}-0.9247 \\
(0.684)\end{array}$ & $\begin{array}{c}-1.5966^{* *} \\
(0.694)\end{array}$ & & & & & $\begin{array}{r}-0.6585 \\
(0.610)\end{array}$ & $\begin{array}{r}-0.9895 \\
(0.634)\end{array}$ & & \\
\hline Starting age of care & & & & & $\begin{array}{l}0.3085 \\
(0.226)\end{array}$ & $\begin{array}{l}0.3025 \\
(0.223)\end{array}$ & & & & & $\begin{array}{l}0.1402 \\
(0.175)\end{array}$ & $\begin{array}{l}0.1196 \\
(0.189)\end{array}$ \\
\hline Child care*Migrant & & $\begin{array}{c}5.5068^{* * * *} \\
(1.655)\end{array}$ & & & & & & $\begin{array}{l}1.9458 \\
(1.226)\end{array}$ & & & & \\
\hline Kindergarten*Migrant & & & & $\begin{array}{l}5.6308^{* * * *} \\
(1.692)\end{array}$ & & & & & & $\begin{array}{l}1.8308 \\
(1.308)\end{array}$ & & \\
\hline Kita*Migrant & & & & $\begin{array}{l}5.0431^{* * *} \\
(2.301)\end{array}$ & & & & & & $\begin{array}{l}2.1591 \\
(1.636)\end{array}$ & & \\
\hline Starting age*Migrant & & & & & & $\begin{array}{l}0.0615 \\
(0.612)\end{array}$ & & & & & & $\begin{array}{l}0.1552 \\
(0.551)\end{array}$ \\
\hline Migrant & $\begin{array}{c}-0.1013 \\
(0.687) \\
\end{array}$ & $\begin{array}{c}-4.7618^{* *} \\
(1.831) \\
\end{array}$ & $\begin{array}{c}-0.0108 \\
(0.718) \\
\end{array}$ & $\begin{array}{c}-4.6290^{* * *} \\
(1.870) \\
\end{array}$ & $\begin{array}{l}0.9291 \\
(0.624) \\
\end{array}$ & $\begin{array}{l}0.7434 \\
(1.971) \\
\end{array}$ & $\begin{array}{r}0.8119 \\
(0.496)\end{array}$ & $\begin{array}{l}-0.7558 \\
(1.144) \\
\end{array}$ & $\begin{array}{c}1.0195^{* *} \\
(0.502)\end{array}$ & $\begin{array}{l}-0.4665 \\
(1.155) \\
\end{array}$ & $\begin{array}{c}1.5386^{* * * *} \\
(0.554)\end{array}$ & $\begin{array}{l}1.0295 \\
(1.789) \\
\end{array}$ \\
\hline$N$ & 3084 & 3084 & 3009 & 3009 & 2655 & 2655 & 5583 & 5583 & 5422 & 5422 & 4679 & 4679 \\
\hline Adj. $R^{2}$ & 0.022 & 0.027 & 0.023 & 0.028 & 0.025 & 0.025 & 0.034 & 0.035 & 0.035 & 0.035 & 0.032 & 0.032 \\
\hline
\end{tabular}


Table 4. Separate subscales for the KINDL sum score

\begin{tabular}{|c|c|c|c|c|c|c|}
\hline & \multicolumn{6}{|c|}{ OLS estimates for the child well-being subscales of the KINDL sum score } \\
\hline & $\begin{array}{r}\text { Physical } \\
\text { well-being }\end{array}$ & $\begin{array}{c}\text { Psychological } \\
\text { well-being }\end{array}$ & Self-esteem & Family & Friends & School \\
\hline & $(1)$ & $(2)$ & (3) & (4) & (5) & (6) \\
\hline \multicolumn{7}{|l|}{$\begin{array}{l}\text { Panel A: Full } \\
\text { sample }\end{array}$} \\
\hline \multicolumn{7}{|c|}{ Child stayed at home as reference } \\
\hline Child care & $\begin{array}{l}-0.5759 \\
(0.583)\end{array}$ & $\begin{array}{c}-1.5049^{* * * *} \\
(0.463)\end{array}$ & $\begin{array}{c}-1.1187^{* *} \\
(0.532)\end{array}$ & $\begin{array}{c}-1.3478^{* * *} \\
(0.474)\end{array}$ & $\begin{array}{c}-1.4299^{* * * *} \\
(0.410)\end{array}$ & $\begin{array}{l}-0.7314 \\
(0.572)\end{array}$ \\
\hline \multirow[t]{2}{*}{ Child care*Migrant } & $2.2368^{*}$ & $3.6322^{* * * *}$ & $4.1749^{* * * *}$ & $2.7887^{* *}$ & $4.2116^{* * * *}$ & 1.5428 \\
\hline & $(1.319)$ & $(1.158)$ & $(1.385)$ & $(1.287)$ & $(1.010)$ & $(1.400)$ \\
\hline \multirow[t]{2}{*}{ Migrant } & -1.3841 & $-2.5808^{* *}$ & $-3.0434^{* *}$ & 1.8351 & $-2.3122^{* * *}$ & $-5.1300^{* * *}$ \\
\hline & $(1.206)$ & $(1.031)$ & $(1.412)$ & $(1.172)$ & $(0.900)$ & $(1.284)$ \\
\hline$N$ & 10745 & 10795 & 10796 & 10847 & 10833 & 10125 \\
\hline Adj. $R^{2}$ & 0.046 & 0.032 & 0.041 & 0.041 & 0.021 & 0.175 \\
\hline \multicolumn{7}{|c|}{ Panel B: Children aged 6 to 9 (elementary school) } \\
\hline \multirow{3}{*}{ Child care } & & Child stayed & ome as refere & & & \\
\hline & -0.6395 & -0.6413 & $-1.6645^{*}$ & -1.0347 & $-1.6671^{* *}$ & -0.6412 \\
\hline & $(0.926)$ & $(0.692)$ & $(0.925)$ & $(0.817)$ & $(0.782)$ & $(0.868)$ \\
\hline \multirow[t]{2}{*}{ Child care*Migrant } & $7.7654^{* * *}$ & $5.5208^{* *}$ & 3.1845 & $4.6695^{* *}$ & $8.3523^{* * *}$ & 2.7263 \\
\hline & $(2.559)$ & $(2.551)$ & $(2.811)$ & $(2.008)$ & $(2.210)$ & $(2.967)$ \\
\hline \multirow[t]{2}{*}{ Migrant } & $-5.0998^{* * *}$ & $-5.4237^{* *}$ & -3.2802 & -0.5621 & $-7.3203^{\text {**** }}$ & $-6.8808^{* *}$ \\
\hline & $(2.410)$ & $(2.685)$ & (3.017) & $(2.246)$ & $(2.192)$ & $(2.951)$ \\
\hline$N$ & 3058 & 3077 & 3079 & 3090 & 3089 & 2712 \\
\hline Adj. $R^{2}$ & 0.010 & 0.014 & 0.020 & 0.036 & 0.024 & 0.070 \\
\hline \multicolumn{7}{|c|}{ Panel C: Children aged 10 to 17 (secondary school) } \\
\hline \multirow{3}{*}{ Child care } & & Child staye & ome as refere & & & \\
\hline & -0.1165 & $-2.0185^{* * * *}$ & -1.1134 & $-1.1274^{*}$ & $-1.5493^{* *}$ & -1.0094 \\
\hline & $(0.790)$ & $(0.643)$ & $(0.689)$ & $(0.677)$ & $(0.602)$ & $(0.705)$ \\
\hline \multirow[t]{2}{*}{ Child care*Migrant } & -0.9093 & $3.1124^{*}$ & $4.6289^{* *}$ & 1.2059 & $3.5963^{* *}$ & 1.5549 \\
\hline & $(1.872)$ & $(1.632)$ & $(1.971)$ & (1.944) & $(1.529)$ & (1.979) \\
\hline \multirow[t]{2}{*}{ Migrant } & 1.0585 & -1.7070 & -2.7075 & $3.7284^{* *}$ & -1.0389 & $-6.2284^{* * * *}$ \\
\hline & $(1.759)$ & $(1.420)$ & (1.844) & $(1.812)$ & (1.408) & (1.813) \\
\hline $\mathrm{N}$ & 5535 & 5558 & 5559 & 5583 & 5577 & 5461 \\
\hline Adj. $R^{2}$ & 0.041 & 0.022 & 0.016 & 0.028 & 0.020 & 0.093 \\
\hline
\end{tabular}

Notes: All reported estimates are weighted nonstandardized regression coefficients. All models include controls for child age, gender, a dummy for having at least one sibling, number of individuals in the household, household net income, parental situation (married, single, living with new partners), parental age, parental education, parental employment, parental occupation, type of region (rural area, small/medium/large city), and East Germany. Robust standard errors clustered on the sampling point level are in parentheses. $* p<.1, * * \mathrm{p}<.05, * * * p<.01$. 
Table 5. Relation between child care and self-assessed KINDL sum score, SDQ sum score, and math/language test scores

OLS estimates for different child outcomes

\begin{tabular}{|c|c|c|c|c|c|c|c|c|c|c|}
\hline & \multicolumn{10}{|c|}{ OLS estimates for different child outcomes } \\
\hline & \multirow{3}{*}{\multicolumn{2}{|c|}{$\begin{array}{l}\text { Children aged } 10 \text { to } 17 \\
\begin{array}{c}\text { KINDL sum score } \\
\text { (self-assessed) }\end{array}\end{array}$}} & \multirow{2}{*}{\multicolumn{4}{|c|}{ Children aged 2 to 17}} & \multirow{2}{*}{\multicolumn{4}{|c|}{ Children aged (6) 8 to 17}} \\
\hline & & & & & & & & & & \\
\hline & & & \multicolumn{2}{|c|}{$\begin{array}{c}\text { SDQ subscale } \\
\text { Pro-social Behavior }\end{array}$} & \multicolumn{2}{|c|}{ SDQ sum score } & \multicolumn{2}{|c|}{ Math score } & \multicolumn{2}{|c|}{ German score } \\
\hline & (1) & (2) & (3) & (4) & (5) & $(6)$ & (7) & (8) & (9) & (10) \\
\hline Child care & $\begin{array}{l}0.0490 \\
(0.561)\end{array}$ & & $\begin{array}{r}-0.1118^{*} \\
(0.063)\end{array}$ & & $\begin{array}{c}\text { yyed at ho } h \text { o. } \\
0.6557^{* * *} \\
(0.162)\end{array}$ & seference & $\begin{array}{l}0.0321 \\
(0.044)\end{array}$ & & $\begin{array}{l}0.0105 \\
(0.036)\end{array}$ & \\
\hline Kindergarten & & $\begin{array}{l}0.0102 \\
(0.564)\end{array}$ & & $\begin{array}{l}-0.0876 \\
(0.064)\end{array}$ & & $\begin{array}{c}0.6127^{* * *} \\
(0.163)\end{array}$ & & $\begin{array}{l}0.0448 \\
(0.044)\end{array}$ & & $\begin{array}{l}0.0112 \\
(0.036)\end{array}$ \\
\hline Kita & & $\begin{array}{l}0.6322 \\
(0.660)\end{array}$ & & $\begin{array}{c}-0.2140^{* * * *} \\
(0.076)\end{array}$ & & $\begin{array}{c}0.7559^{* * * *} \\
(0.216)\end{array}$ & & $\begin{array}{l}-0.0212 \\
(0.054)\end{array}$ & & $\begin{array}{l}0.0021 \\
(0.045)\end{array}$ \\
\hline Child care*Migrant & $\begin{array}{l}1.4891 \\
(1.470)\end{array}$ & & $\begin{array}{l}0.1305 \\
(0.160)\end{array}$ & & $\begin{array}{r}-0.7055^{*} \\
(0.368)\end{array}$ & & $\begin{array}{l}0.1511^{*} \\
(0.086)\end{array}$ & & $\begin{array}{l}0.0055 \\
(0.090)\end{array}$ & \\
\hline Kindergarten*Migrant & & $\begin{array}{l}1.5878 \\
(1.391)\end{array}$ & & $\begin{array}{l}0.1335 \\
(0.164)\end{array}$ & & $\begin{array}{l}-0.5648 \\
(0.377)\end{array}$ & & $\begin{array}{l}0.2108^{* *} \\
(0.090)\end{array}$ & & $\begin{array}{l}0.0165 \\
(0.095)\end{array}$ \\
\hline Kita*Migrant & & $\begin{array}{l}-0.3863 \\
(2.161)\end{array}$ & & $\begin{array}{l}0.0489 \\
(0.242)\end{array}$ & & $\begin{array}{l}-0.4686 \\
(0.580)\end{array}$ & & $\begin{array}{l}-0.0114 \\
(0.152)\end{array}$ & & $\begin{array}{r}-0.0487 \\
(0.141)\end{array}$ \\
\hline Migrant & $\begin{array}{r}-2.5117^{*} \\
(1.313) \\
\end{array}$ & $\begin{array}{r}-2.2870^{*} \\
(1.320) \\
\end{array}$ & $\begin{array}{l}-0.0677 \\
(0.153) \\
\end{array}$ & $\begin{array}{l}-0.0387 \\
(0.151)\end{array}$ & $\begin{array}{l}0.8114^{* *} \\
(0.363)\end{array}$ & $\begin{array}{c}0.7245^{* *} \\
(0.359) \\
\end{array}$ & $\begin{array}{c}-0.2672^{* * *} \\
(0.086) \\
\end{array}$ & $\begin{array}{c}-0.2808^{* * * *} \\
(0.088) \\
\end{array}$ & $\begin{array}{l}0.0742 \\
(0.087)\end{array}$ & $\begin{array}{l}0.0662 \\
(0.087) \\
\end{array}$ \\
\hline$N$ & 4771 & 4628 & 10897 & 10596 & 10885 & 10586 & 6477 & 6297 & 6468 & 6286 \\
\hline Adj. $R^{2}$ & 0.051 & 0.054 & 0.032 & 0.033 & 0.093 & 0.094 & 0.126 & 0.129 & 0.184 & 0.187 \\
\hline
\end{tabular}

Notes: All models include controls for child age, gender, dummy for having at least one sibling, number of individuals in the household, household net income, parental situation (married, single, living with new partners), parental age, parental education, parental employment, parental occupation, type of region (rural area, small/medium/large city), and East Germany. Robust standard errors clustered on the sampling point level are in parentheses. $* p<.1, * * p<.05, * * * p<.01$. 
Table 6. OLS estimates for the KINDL child well-being measure for children 3-17 without controls

\begin{tabular}{|c|c|c|c|c|c|c|}
\hline & \multicolumn{6}{|c|}{ OLS estimates for child well-being measured by the KINDL sum score } \\
\hline & \multicolumn{4}{|c|}{ Sample I } & \multicolumn{2}{|c|}{ Sample II } \\
\hline & (1) & $(2)$ & (3) & (4) & (5) & $(6)$ \\
\hline Child care & $\begin{array}{c}-0.5432 * \\
(0.306)\end{array}$ & $\begin{array}{c}\text { ild stayed at } \\
-0.9933 * * * \\
(0.332)\end{array}$ & me as referen & & & \\
\hline Kindergarten & & & $\begin{array}{c}-0.5104 \\
(0.321)\end{array}$ & $\begin{array}{c}-0.9674 * * * \\
(0.351)\end{array}$ & & \\
\hline Kita & & & $\begin{array}{c}-0.6198 * \\
(0.333)\end{array}$ & $\begin{array}{c}-1.0010 * * * \\
(0.362)\end{array}$ & & \\
\hline Starting age of care & & & & & $\begin{array}{l}0.0894 \\
(0.099)\end{array}$ & $\begin{array}{l}0.0737 \\
(0.105)\end{array}$ \\
\hline Child care*Migrant & & $\begin{array}{c}2.2661 * * * \\
(0.738)\end{array}$ & & & & \\
\hline Kindergarten*Migrant & & & & $\begin{array}{c}2.3615 * * * \\
(0.739)\end{array}$ & & \\
\hline Kita*Migrant & & & & $\begin{array}{l}1.8900^{*} \\
(1.005)\end{array}$ & & \\
\hline Starting age* Migrant & & & & & & $\begin{array}{l}0.1401 \\
(0.322)\end{array}$ \\
\hline Migrant & $\begin{array}{c}-0.6952 * * \\
(0.291)\end{array}$ & $\begin{array}{c}-2.4779 * * * \\
(0.647)\end{array}$ & $\begin{array}{c}-0.5824 * \\
(0.316)\end{array}$ & $\begin{array}{c}-2.3202 * * * \\
(0.646)\end{array}$ & $\begin{array}{l}-0.0718 \\
(0.352)\end{array}$ & $\begin{array}{c}-0.5094 \\
(1.033)\end{array}$ \\
\hline Age & $\begin{array}{c}-1.1995 * * * \\
(0.040)\end{array}$ & $\begin{array}{c}-1.1979 * * * \\
(0.040)\end{array}$ & $\begin{array}{c}-1.2030 * * * \\
(0.041)\end{array}$ & $\begin{array}{c}-1.2009 * * * \\
(0.040)\end{array}$ & $\begin{array}{c}-1.2296 * * * \\
(0.049)\end{array}$ & $\begin{array}{c}-1.2301 * * * \\
(0.049)\end{array}$ \\
\hline Male & $\begin{array}{c}-0.0542 \\
(0.178)\end{array}$ & $\begin{array}{c}-0.0448 \\
(0.178)\end{array}$ & $\begin{array}{l}-0.0403 \\
(0.183)\end{array}$ & $\begin{array}{c}-0.0320 \\
(0.183)\end{array}$ & $\begin{array}{l}-0.0993 \\
(0.190)\end{array}$ & $\begin{array}{c}-0.1004 \\
(0.190)\end{array}$ \\
\hline Constant & $\begin{array}{c}84.5365^{* * * *} \\
(0.339)\end{array}$ & $\begin{array}{c}84.9053 * * * \\
(0.358) \\
\end{array}$ & $\begin{array}{c}84.5626^{* * * *} \\
(0.348)\end{array}$ & $\begin{array}{c}84.9151 * * * \\
(0.365) \\
\end{array}$ & $\begin{array}{c}83.8934 * * * \\
(0.390)\end{array}$ & $\begin{array}{c}83.9412 * * * \\
(0.416)\end{array}$ \\
\hline$N$ & 14225 & 14225 & 13731 & 13731 & 11768 & 11768 \\
\hline Adj. $R^{2}$ & 0.071 & 0.072 & 0.071 & 0.072 & 0.071 & 0.071 \\
\hline
\end{tabular}


Table 7. 2SLS estimates for the KINDL child well-being measure using Lewbel's method.

\begin{tabular}{|c|c|c|c|c|c|c|}
\hline & \multicolumn{6}{|c|}{ 2SLS estimates for child well-being measured by the KINDL sum score } \\
\hline & \multicolumn{4}{|c|}{ Sample I } & \multicolumn{2}{|c|}{ Sample II } \\
\hline & (1) & (2) & (3) & (4) & $(5)$ & (6) \\
\hline Child care & $\begin{array}{l}C \\
-0.5520 \\
(0.431)\end{array}$ & $\begin{array}{c}\text { ld stayed at } \\
-0.9506^{* *} \\
(0.391)\end{array}$ & me as refere & & & \\
\hline Kindergarten & & & $\begin{array}{c}-0.4498 \\
(0.426)\end{array}$ & $\begin{array}{c}-0.7885^{* * *} \\
(0.304)\end{array}$ & & \\
\hline Kita & & & $\begin{array}{r}-0.6381 \\
(0.790)\end{array}$ & $\begin{array}{c}-0.6272 \\
(0.463)\end{array}$ & & \\
\hline Starting age of care & & & & & $\begin{array}{l}0.1011 \\
(0.296)\end{array}$ & $\begin{array}{l}0.2594 \\
(0.242)\end{array}$ \\
\hline Child care*Migrant & & $\begin{array}{c}2.8720^{* * * *} \\
(0.826)\end{array}$ & & & & \\
\hline Kindergarten*Migrant & & & & $\begin{array}{c}2.7127^{* * * *} \\
(0.811)\end{array}$ & & \\
\hline Kita*Migrant & & & & $\begin{array}{l}2.0508^{*} \\
(1.048)\end{array}$ & & \\
\hline Starting age* Migrant & & & & & & $\begin{array}{l}0.2187 \\
(0.433)\end{array}$ \\
\hline Migrant & $\begin{array}{l}0.5579 \\
(0.362)\end{array}$ & $\begin{array}{c}-1.7684^{* *} \\
(0.772)\end{array}$ & $\begin{array}{c}0.6478^{*} \\
(0.370)\end{array}$ & $\begin{array}{c}-1.6775^{* *} \\
(0.737)\end{array}$ & $\begin{array}{c}1.3723^{* * * *} \\
(0.405)\end{array}$ & $\begin{array}{l}0.6609 \\
(1.338)\end{array}$ \\
\hline Age & $\begin{array}{c}-1.3118^{* * * *} \\
(0.057)\end{array}$ & $\begin{array}{c}-1.3102^{* * *} \\
(0.057)\end{array}$ & $\begin{array}{c}-1.3103^{* * * *} \\
(0.059)\end{array}$ & $\begin{array}{c}-1.3417^{* * *} \\
(0.052)\end{array}$ & $\begin{array}{c}-1.3422^{* * * *} \\
(0.074)\end{array}$ & $\begin{array}{c}-1.3587^{* * * *} \\
(0.074)\end{array}$ \\
\hline Male & $\begin{array}{c}-0.3052 \\
(0.201)\end{array}$ & $\begin{array}{r}-0.2931 \\
(0.201)\end{array}$ & $\begin{array}{l}-0.3239 \\
(0.202)\end{array}$ & $\begin{array}{r}-0.1427 \\
(0.178)\end{array}$ & $\begin{array}{r}-0.3633 \\
(0.225)\end{array}$ & $\begin{array}{c}-0.3701^{*} \\
(0.224)\end{array}$ \\
\hline Sibling in $\mathrm{HH}$ & $\begin{array}{c}-0.0867 \\
(0.731)\end{array}$ & $\begin{array}{c}-0.0904 \\
(0.740)\end{array}$ & $\begin{array}{c}-0.1769 \\
(0.762)\end{array}$ & $\begin{array}{c}-0.4362 \\
(0.574)\end{array}$ & $\begin{array}{l}0.8242 \\
(0.717)\end{array}$ & $\begin{array}{l}0.7949 \\
(0.715)\end{array}$ \\
\hline Net income $\mathrm{HH}$ & $\begin{array}{c}0.2792^{* * * *} \\
(0.054)\end{array}$ & $\begin{array}{c}0.2759^{* * * *} \\
(0.054)\end{array}$ & $\begin{array}{c}0.2865^{* * * *} \\
(0.055)\end{array}$ & $\begin{array}{c}0.2484^{* * * *} \\
(0.045)\end{array}$ & $\begin{array}{c}0.2881^{* * * *} \\
(0.061)\end{array}$ & $\begin{array}{c}0.2908^{* * * *} \\
(0.061)\end{array}$ \\
\hline Parental situation & \multicolumn{6}{|c|}{ Parents married and living together as a reference } \\
\hline Mother with partner & $\begin{array}{c}-1.7932^{\text {*** }} \\
(0.517)\end{array}$ & $\begin{array}{c}-1.8067^{* * * *} \\
(0.518)\end{array}$ & $\begin{array}{c}-1.7669^{* * * *} \\
(0.524)\end{array}$ & $\begin{array}{c}-1.8364^{* * *} \\
(0.398)\end{array}$ & $\begin{array}{c}-1.7329^{* * *} \\
(0.536)\end{array}$ & $\begin{array}{c}-1.7007^{\text {**** }} \\
(0.538)\end{array}$ \\
\hline Father with partner & $\begin{array}{c}-5.2856^{* * * *} \\
(1.787)\end{array}$ & $\begin{array}{c}-5.2593^{\text {**** }} \\
(1.785)\end{array}$ & $\begin{array}{c}-5.4349^{* * * *} \\
(1.798)\end{array}$ & $\begin{array}{c}-3.7836^{* *} \\
(1.492)\end{array}$ & $\begin{array}{c}-5.4107^{* * * *} \\
(1.961)\end{array}$ & $\begin{array}{c}-5.4003^{* * * *} \\
(1.953)\end{array}$ \\
\hline Single mother & $\begin{array}{c}-1.3795^{*} \\
(0.823)\end{array}$ & $\begin{array}{c}-1.4379^{*} \\
(0.824)\end{array}$ & $\begin{array}{c}-1.4573^{*} \\
(0.850)\end{array}$ & $\begin{array}{c}-1.6355^{* *} \\
(0.647)\end{array}$ & $\begin{array}{c}-2.3697^{* *} \\
(0.930)\end{array}$ & $\begin{array}{c}-2.3604^{* * *} \\
(0.932)\end{array}$ \\
\hline Single father & $\begin{array}{c}-0.2616 \\
(1.374)\end{array}$ & $\begin{array}{r}-0.3099 \\
(1.383)\end{array}$ & $\begin{array}{r}-0.0625 \\
(1.414)\end{array}$ & $\begin{array}{r}-0.1937 \\
(1.373)\end{array}$ & $\begin{array}{r}-0.6969 \\
(1.673)\end{array}$ & $\begin{array}{r}-0.7021 \\
(1.673)\end{array}$ \\
\hline Other & $\begin{array}{c}-3.8436^{* * * *} \\
(1.245)\end{array}$ & $\begin{array}{c}-3.8895^{* * * *} \\
(1.248)\end{array}$ & $\begin{array}{c}-4.2006^{* * * *} \\
(1.266)\end{array}$ & $\begin{array}{c}-4.5709^{* * * *} \\
(1.239)\end{array}$ & $\begin{array}{c}-3.9861^{* * * *} \\
(1.345)\end{array}$ & $\begin{array}{c}-4.0188^{* * * *} \\
(1.349)\end{array}$ \\
\hline \multirow{2}{*}{$\begin{array}{l}\text { Type of region } \\
\text { Small city }\end{array}$} & \multicolumn{6}{|c|}{ Rural area as a reference } \\
\hline & $\begin{array}{c}-0.4283 \\
(0.320)\end{array}$ & $\begin{array}{r}-0.4219 \\
(0.318)\end{array}$ & $\begin{array}{c}-0.3758 \\
(0.317)\end{array}$ & $\begin{array}{l}-0.2116 \\
(0.246)\end{array}$ & $\begin{array}{c}-0.2180 \\
(0.395)\end{array}$ & $\begin{array}{l}-0.2081 \\
(0.392)\end{array}$ \\
\hline Medium city & $\begin{array}{r}-0.0759 \\
(0.341)\end{array}$ & $\begin{array}{r}-0.0547 \\
(0.337)\end{array}$ & $\begin{array}{l}-0.0765 \\
(0.338)\end{array}$ & $\begin{array}{l}-0.1424 \\
(0.250)\end{array}$ & $\begin{array}{r}-0.0777 \\
(0.400)\end{array}$ & $\begin{array}{l}-0.0662 \\
(0.399)\end{array}$ \\
\hline Large city & $\begin{array}{c}-0.1440 \\
(0.353)\end{array}$ & $\begin{array}{c}-0.1534 \\
(0.349)\end{array}$ & $\begin{array}{r}-0.1299 \\
(0.366)\end{array}$ & $\begin{array}{c}-0.1190 \\
(0.277)\end{array}$ & $\begin{array}{c}-0.2709 \\
(0.408)\end{array}$ & $\begin{array}{r}-0.2571 \\
(0.406)\end{array}$ \\
\hline East Germany & $\begin{array}{c}1.5677^{* * * *} \\
(0.304)\end{array}$ & $\begin{array}{c}1.6230^{* * * *} \\
(0.299)\end{array}$ & $\begin{array}{c}1.6791^{* * * *} \\
(0.453)\end{array}$ & $\begin{array}{c}1.3487^{* * *} \\
(0.289)\end{array}$ & $\begin{array}{c}1.7483^{* * * *} \\
(0.448)\end{array}$ & $\begin{array}{c}1.9249^{* * * *} \\
(0.405)\end{array}$ \\
\hline Constant & $\begin{array}{c}81.5956^{* * * *} \\
(1.292)\end{array}$ & $\begin{array}{c}82.1256^{* * * *} \\
(1.295)\end{array}$ & $\begin{array}{c}81.4206^{* * * *} \\
(1.346)\end{array}$ & $\begin{array}{c}82.2685^{* * * *} \\
(1.147)\end{array}$ & $\begin{array}{c}80.9023^{* * * *} \\
(1.708)\end{array}$ & $\begin{array}{c}80.5037^{* * * *} \\
(1.676)\end{array}$ \\
\hline$N$ & 10835 & 10835 & 10536 & 10536 & 9088 & 9088 \\
\hline Adj. $R^{2}$ & 0.083 & 0.085 & 0.084 & 0.089 & 0.086 & 0.086 \\
\hline
\end{tabular}

Notes: Sample I includes all children: Sample II includes only children reported to have experienced some preschool child care. All models include controls for number of individuals in the household, parental age, parental education, parental employment, and parental occupation. Model 1-3 and 5-6 use sample weights. Robust standard errors are clustered on the sampling point level for all models except model 4, which uses a bootstrapped test statistic and no sample weights. $* p<$ $.1, * * p<.05, * * * p<.01$. Results supported by Stata's IVREG2H command (Baum \& Schaffer, 2012) 